\title{
Analysis of morpho-anatomical stem properties determining its mechanical strength in selected rye cultivars**
}

\author{
Tomasz Wójtowicz*®D, Aleksandra Grabowska-Joachimiak@, and Andrzej Zieliński@ \\ Department of Plant Breeding, Physiology and Seed Science, University of Agriculture in Kraków, Faculty of Agriculture \\ and Economics, Podłużna 3, 30-239, Kraków, Poland
}

Received June 12, 2019; accepted December 5, 2019

\begin{abstract}
The objective of the research was to compare important properties of the morphological and anatomical structure of stems of four open-pollinated rye cultivars in relation to their mechanical strength expressed by the failure moment, taking into account the possibility of using the stems for the manufacture of natural drinking straws. From the 2 nd and the $3 \mathrm{rd}$ stem internodes, cross sections were obtained within which the number of large vascular bundles, the diameters of the stem and the central canal, as well as the thicknesses of the stem wall, sclerenchyma and parenchyma were determined. The differentiation in cultivar properties was mainly affected by the location of the internode within the stem. The stem diameter ranged from $5.2 \mathrm{~mm}$ (Dańkowskie Rubin) to $5.4 \mathrm{~mm}$ (Antonińskie). As compared with the $3 \mathrm{rd}$ internode, in the 2 nd internode the values of the analysed traits ranged from 5 to $25 \%$ higher. In both internodes a significant correlation $(r>0.680, p<0.01)$ between the stem diameter and the central canal diameter was found. In all the cultivars the failure moment depended significantly on the stem diameter for both the internodes $(r>0.638, p<0.01)$. The analyses carried out show that the 2nd internode is characterized by the most favourable properties affecting the mechanical strength of rye stems.
\end{abstract}

Keyw ords: Secale cereale, biodegradable straws, mechanical properties, failure moment $(B S)$, stem anatomy

\section{INTRODUCTION}

Rye (Secale cereale L.) is one of the main cereal species grown mainly as a winter crop in low temperature regions of Northern, Central and Eastern Europe. In Poland, it is sown over an area of approximately 870000 ha, which is $>12 \%$ of the total area of cereal crops (LOO, 2018). Apart from Poland it is cultivated in Germany (523000 ha), Sweden (19500 ha) Russia (1259000 ha) and Belarus

*Corresponding author e-mail: tomasz.wojtowicz@urk.edu.pl **This work was financed by the Ministry of Science and Higher Education of the Republic of Poland (2017-2019).
(323000 ha), where it is still a common bread-making crop (FAOSTAT, 2019). The soil requirements of rye are less demanding than for other cereal crops, it can be grown on light and poor soils and it tolerates soil acidity well (Falke et al., 2009). With its well-developed root system rye is resistant to drought; it is also characterized by a high resistance to frost, pathogens and high fertility. The grain of this natural diploid species $(2 n=14)$ contains many valuable nutritional components, such as fibre, mineral substances, antioxidants, vitamins and polyphenols (Călinoiu and Vodnar, 2018). The byproduct yield - straw is commonly used as fodder and litter, as well as organic fertilizer. Straw may also be used as a raw material for the production of disposable, biodegradable articles, with particular regard to drinking straws, which seems to be an inventive and promising approach. The findings of the Institute for European Environmental Policy have confirmed the presence of disposable plastic products in seas and oceans. Each year, their volume increases at an alarming rate; it is assessed to range from 4.8 to even 12.7 million $t$ (Jambeck et al., 2015). The producers of ecological food components have indicated an urgent need for the use of natural substitutes for omnipresent polyurethanes. According to the recommendations of the relevant EU Directive, the use of plastic products which cannot currently be replaced will have to be reduced by EU member countries in an "ambitious and durable way" till the year 2025 (EC, 2018). Thus, an urgent search is taking place for both natural and biodegradable components for the manufacture of disposable products, the demand for which in Europe alone is assessed to reach 50 million $\mathrm{t}$.

(C) 2020 Institute of Agrophysics, Polish Academy of Sciences 
The fixed forms, i.e. cylindrical, straight stems consisting of 4-6 internodes which occur in open-pollinated cultivars of winter rye, and which are much higher compared with hybrid cultivars, are of special significance in the production of, for instance, natural drinking straws. When choosing an adequate form, it is important to consider, apart from the length of the stem, its mechanical strength, including resistance to crushing and breaking. In the case of contemporary breeding creations in the Secale genus, the maximization of yield is prioritized, the average mechanical strength of the stems, especially in the context of the lodging is a significant problem (Baron et al., 2015). Apart from the practices aimed at reducing plant height (using growth regulators or introducing dwarf genes) resistance to lodging is strongly modified through the morphological and anatomical properties of the stem structure (Šíp et al., 2010). In the case of using rye straw in the production of organic food products, stem shortening seems to be economically unjustified, in contrast to the selection of forms with high stem stiffness conditioned by genotype.

The objective of the research was to compare the most important properties of the morphological and anatomical structure of stems in four open-pollinated cultivars of rye in relation to their mechanical strength determined on the basis of the stem failure moment $(B S)$, taking into consideration the possible use of stems for the manufacture of natural drinking straws.

\section{MATERIAL AND METHODS}

Polish winter rye cultivars: Dańkowskie Diament, Dańkowskie Rubin, Dańkowskie Amber (Danko Plant Breeding Sp. z o.o.) and Antonińskie (PHR - Poznań Plant Breeding Sp. z o.o.) were used in the study. The selection was performed on the basis of the stem diameter, resistance to lodging and length of the internodes. The cultivars were grown at the Experimental Station of the Polish Research Centre for Cultivar Testing in Pawłowice (Poland, $50^{\circ} 28^{\prime} \mathrm{N}$, $\left.18^{\circ} 29^{\prime} \mathrm{E}\right)$. The station is located on arable soil, typical for winter rye cultivation with $\mathrm{pH} 6.45$ (in $\mathrm{KCl}$ ). The mineral fertilization used included $\mathrm{N}$ at $124 \mathrm{~kg} \mathrm{ha}^{-1}, \mathrm{P}\left(\mathrm{P}_{2} \mathrm{O}_{5}\right)$ at $80 \mathrm{~kg} \mathrm{ha}^{-1}$ and $\mathrm{K}\left(\mathrm{K}_{2} \mathrm{O}\right)$ at $120 \mathrm{~kg} \mathrm{ha}^{-1}$. The grains were treated with Maxim 025FS $\left(0.2 \mathrm{~L} 100 \mathrm{~kg}^{-1}\right)$. The plants were protected against weeds with Boxer $800 \mathrm{EC}\left(2 \mathrm{~L} \mathrm{ha}^{-1}\right)$ and Legato $500 \mathrm{SC}\left(0.2 \mathrm{~L} \mathrm{ha}^{-1}\right)$. The insecticide Karate Zeon $050 \mathrm{CS}\left(0.12 \mathrm{~L} \mathrm{ha}^{-1}\right)$ was applied preventively.

At the beginning of July 2017 at stage 73 in the BBCH scale (Lancashire et al., 1991), 30 stems of each cultivar were randomly collected.

Further procedures for each cultivar were as follows: 1) the morphological traits, such as the total length of the stem as well as the number and length of internodes were determined, 2) from ten randomly selected stems, the 2nd and the 3rd internodes were cut off, 3 ) after the removal of the leaf sheaths they were fixed in $70 \%$ ethanol and stored at room temperature for a few weeks, 4) from the middle part of each internode a $10 \mathrm{~cm}$ long segment was excised and used to prepare the cross sections.

From each internode, $25 \mu \mathrm{m}$ thick cross sections were made using a hand microtome (MT.5503, EUROMEX microscopes-Holland). The sections were double stained with $1 \%$ safranin solution in $50 \%$ ethanol and $1 \%$ alcian blue solution in $1 \%$ acetic acid. The sections were placed in safranin solution for $2 \mathrm{~min}$. and subsequently rinsed in $96 \%$ ethanol and in distilled water. Then they were stained with alcian blue solution for $6 \mathrm{~min}$, and after being rinsed in distilled water they were dehydrated in ethanol (96 and 100\%) and immersed in xylene. Next, the sections were put onto microscope slides and mounted in Entellan ${ }^{\circledR}$ new. Finally, twenty of the best-stained sections were selected for anatomical analysis and measurements.

Additionally, in order to determine the extent of cell wall lignification, for each cultivar several cross sections were stained histochemically using the Wiesner reaction. For this purpose the sections were treated with $2 \%$ phloroglucinol solution in $92 \%$ ethanol, and then they were mounted in 6 $\mathrm{M} \mathrm{HCl}$ and immediately microscopically examined.

Microphotographs of the stem cross sections were taken under a stereoscopic microscope (Zeiss Stemi-SV11) using an Opta-Tech camera and OptaView 7 software and also under a light microscope (Nikon Microphot-FXA) equipped with a Nikon DS-Filc camera and NIS Elements software. The images were used for anatomical evaluation.

The following measurements using ImageJ software (Rueden et al., 2017) were performed for each cultivar tested:

- outer and inner stem diameters (the inner diameter corresponds to the lumen diameter) - an average of two measurements were taken diagonally

- stem wall thickness, the thickness of the sclerenchyma ring (including the epidermis) and the thickness of the parenchyma layer - in each case an average of four radial measurements were taken in different positions (in a region deprived of vascular bundles).

Moreover, the number of big vascular bundles (embedded in the parenchyma tissue) within both internodes (II and III) was determined.

The mechanical strength of the stem was determined on the basis of the stem failure moment value $(B s)$ :

$$
B s=\frac{\sigma \pi a}{4}\left(1-\left(\frac{a-t}{a}\right)^{4}\right),
$$

where: $\sigma$ is the stem yield strength, $a$ is the stem radius, and $t$ is the stem wall thickness. The value of $\sigma$ was assumed to be $40 \mathrm{~N} \mathrm{~m}^{-2}$ (Baker et al., 1998).

A two-way ANOVA, with rye cultivars and internode positions as the factors, was carried out. The differentiation of the mean values for the analysed parameters was determined on the basis of the Tukey HSD test at $p<0.05$. The 
components of variance were estimated and their percentages were given (Searle et al., 2006). The interrelationship between the estimated parameters of the stem was determined on the basis of the Pearson correlation coefficient. A statistical analysis was carried out with the use of Statistica 13 (Dell Inc. 2016).

\section{RESULTS}

The stem cross sections of the investigated rye cultivars showed a tissue arrangement typical of cereal stem anatomy (Fig. 1). Under a single layer of thick-walled epidermal cells there was extensive sclerenchyma forming the hypodermal mechanical tissue. Two concentric rings of vascular bundles were noted within the analysed internodes. Small, external bundles were embedded in the sclerenchyma layer and wing-shaped chlorenchyma clusters located on both sides of each such bundle could usually be observed. Large, internal bundles surrounded by sclerenchymatous sheaths were arranged within the parenchyma tissue, which occupied the area from the subepidermal sclerenchyma to the central cavity of the stem.

Histochemical staining with Wiesner's reagents was used to confirm the lignification of the cell walls, which were stained red with safranin (Fig. 2). In the case of each cultivar studied, the result of the colour reaction was very similar. The walls of epidermal and sclerenchyma cells, vessels, tracheids, as well as the walls of most parenchyma cells showed a positive reaction after phloroglucinol- $\mathrm{HCl}$ treatment. It was clearly visible that only the parenchyma cells directly adjacent to the central cavity possessed unstained walls, deprived of lignin encrustation.

The mean values of the parameters obtained for the collected stems, such as the length, number of internodes and the lengths of the 2nd and 3rd internodes, are presented in Table 1. Only in the length of the stem, which ranged from $119 \mathrm{~cm}$ in Dańkowskie Amber to $137 \mathrm{~cm}$ in Dańkowskie Rubin were significant differences found.

The tested rye cultivars were characterized by similar differences in the morphological structure of the internodes. The stem diameter, central canal diameter, stem wall thickness, parenchyma thickness, number of large vascular bundles, as well as the stem failure moment value $(B s)$ depended to a large extent on the location of the internode from which the sections were taken for measure-

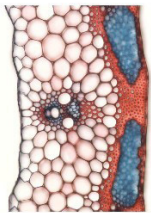

A

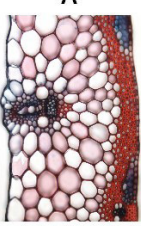

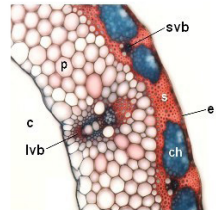

B

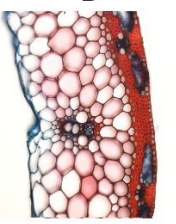

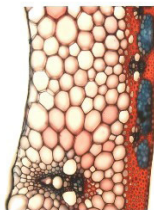

C

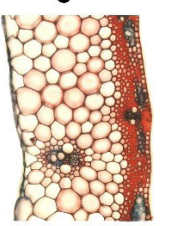

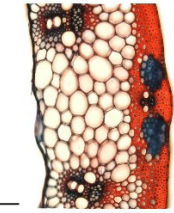

D
Fig. 1. Fragments of the stem cross sections of $S$. cereale cultivars double-stained with safranin and alcian blue: A - Dankowskie Rubin, B - Dańkowskie Diament, C - Dańkowskie Amber, D - Antonińskie; the 2nd internode (upper row), the 3rd internode (lower row); $\mathrm{e}$ - epidermis, $\mathrm{s}$ - sclerenchyma, ch - chlorenchyma, p - parenchyma, c - cavity, svb - small vascular bundle, lvb large vascular bundle; scale bar $=100 \mu \mathrm{m}$.

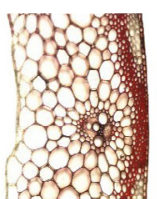

A

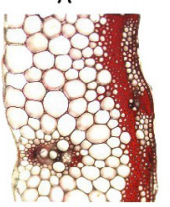

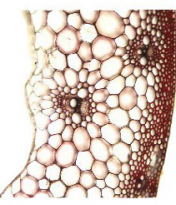

B

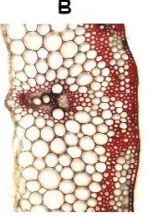

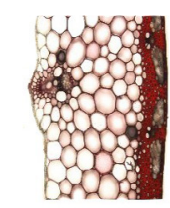

c

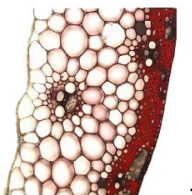

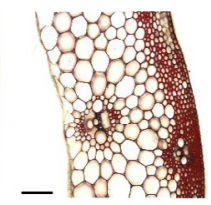

D

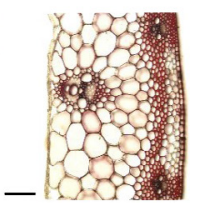

Fig. 2. Fragments of stem cross sections of $S$. cereale cultivars after the Wiesner reaction showing cell wall lignification (red): A - Dańkowskie Rubin, B - Dańkowskie Diament, C - Dańkowskie Amber, D - Antonińskie; the 2nd internode (upper row), the 3rd internode (lower row); scale bar $=100 \mu \mathrm{m}$.

ment (Table 2). The remaining part, not exceeding $20 \%$ of the variability of the aforementioned traits, was due to the cultivar factor. When assessing the analysed parameters, it was found that the percentage of the interaction between cultivar variability and the location of the internodes, considering the thickness of walls, parenchyma thickness and the stem failure moment, although significant, was very low and did not exceed $4 \%$.

Table 1. Mean values $( \pm \mathrm{SD})$ of the selected stem indices for the examined winter rye cultivars

\begin{tabular}{lcccc}
\hline \multirow{2}{*}{ Cultivar } & Mean stem length $(\mathrm{cm})$ & $\begin{array}{c}\text { Range of the number } \\
\text { of internodes }\end{array}$ & \multicolumn{2}{c}{ Mean length $(\mathrm{cm})$} \\
\hline Dańkowskie Diament & $127.4^{\mathrm{b}} \pm 10.9$ & $3-6$ & $20.4^{\mathrm{a}} \pm 5.6$ & 3 3rd internode \\
Dańkowskie Rubin & $136.8^{\mathrm{a}} \pm 10.4$ & $4-5$ & $21.1^{\mathrm{a}} \pm 5.3$ & $34.6^{\mathrm{a}} \pm 9.3$ \\
Dańkowskie Amber & $118.9^{\mathrm{c}} \pm 10.6$ & $4-5$ & $18.3^{\mathrm{a}} \pm 3.3$ & $31.7^{\mathrm{a}} \pm 10.1$ \\
Antonińskie & $132.2^{\mathrm{ab}} \pm 11.9$ & $4-6$ & $19.5^{\mathrm{a}} \pm 4.1$ & $30.9^{\mathrm{a}} \pm 8.3$ \\
\hline
\end{tabular}

Means marked with the same letter do not differ significantly according to the Tukey HSD. 
Table 2. Significance of the selected sources of variability and the percentage share (\%) of the components of variance in the variability of the analyzed stem traits in the studied rye cultivars

\begin{tabular}{|c|c|c|c|c|c|c|c|c|}
\hline \multirow[b]{2}{*}{$\begin{array}{l}\text { Source } \\
\text { of variability }\end{array}$} & \multirow[b]{2}{*}{$d f$} & \multicolumn{7}{|c|}{ Trait } \\
\hline & & $\begin{array}{c}\text { Stem } \\
\text { diameter }\end{array}$ & $\begin{array}{c}\text { Central } \\
\text { canal } \\
\text { diameter }\end{array}$ & $\begin{array}{l}\text { Stem wall } \\
\text { thickness }\end{array}$ & $\begin{array}{l}\text { Sclerenchyma } \\
\text { thickness }\end{array}$ & $\begin{array}{c}\text { Parenchyma } \\
\text { thickness }\end{array}$ & $\begin{array}{l}\text { Number } \\
\text { of large } \\
\text { bundles }\end{array}$ & $\begin{array}{c}\text { Stem failure } \\
\text { moment } B s\end{array}$ \\
\hline Cultivar (A) & 3 & 3.6 & $15.1^{*}$ & $13.2 * *$ & $61.9 * *$ & $19.9 * *$ & $25.7 * *$ & $5.2 *$ \\
\hline $\begin{array}{l}\text { Location of the } \\
\text { internode (B) }\end{array}$ & 1 & $91.5^{* *}$ & $76.7 * *$ & $82.4 * *$ & $34.1 * *$ & $76.3 * *$ & $69.1^{* *}$ & $90.8^{* *}$ \\
\hline $\mathrm{A} \times \mathrm{B}$ & 3 & 1.7 & 0.3 & $3.1^{*}$ & 2.2 & $2.4^{*}$ & 0.4 & $2.5^{*}$ \\
\hline Error & 112 & 3.2 & 7.8 & 1.2 & 1.8 & 1.4 & 4.8 & 1.4 \\
\hline
\end{tabular}

$*$, ** significant at $\mathrm{p}<0.05, \mathrm{p}<0.01$, respectively.

The average stem diameter in all of the genotypes did not differ significantly and its values ranged from $5.2 \mathrm{~mm}$ in Dańkowskie Rubin to $5.4 \mathrm{~mm}$ in Antonińskie. In the 2nd internode, the stem diameter and the diameter of the central canal were on average $0.4 \mathrm{~mm}$ and $0.2 \mathrm{~mm}$ larger, respectively, as compared with the 3rd internode (Fig. 3). The cultivars Dańkowskie Amber and Dańkowskie Diament were characterized by the significantly greater (an increase of $0.5 \mathrm{~mm}$ ) thickness of the stem wall compared with other genotypes, which was directly connected with the central canal diameter (Fig. 4). At the same time, in the 2nd internode the stem wall thickness was, on average, $0.08 \mathrm{~mm}$ greater than in the 3 rd internode.
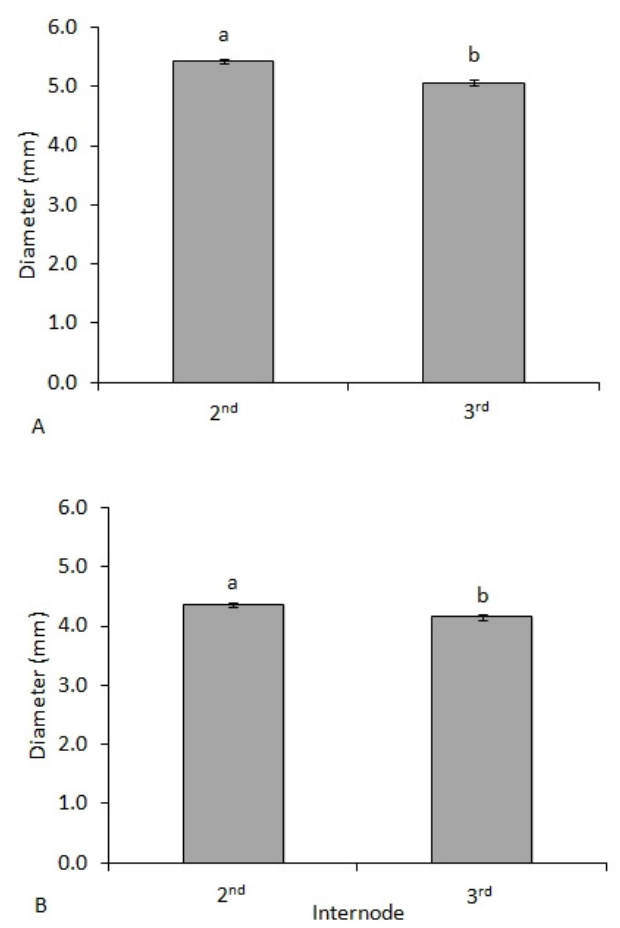

Fig. 3. Differentiation in the stem diameter: A - and central canal diameter, B - in the 2nd and 3rd internodes (the means marked with the same letter do not differ significantly according to the Tukey HSD test at $\mathrm{p}<0.05$; error bars represent mean values \pm standard error).
The number of large vascular bundles and the thickness of the sclerenchyma and parenchyma were shaped to a significant extent by cultivar variability and the location of the internode on the stem (Fig. 5). In the 2nd internode, the number of large bundles was, on average, increased by 2 . In the majority of genotypes, 28 vascular bundles, on average, were found, and only in the cultivar Antonińskie it was significantly lower (25). At the same time, the layer of the sclerenchyma and parenchyma tissues in the 2 nd internode was 0.009 and $0.06 \mathrm{~mm}$ thicker, respectively, as compared with the 3rd one (Fig. 4).

The mechanical properties of the stem as expressed by the value of the failure moment $(B s)$ proved to be significantly better in the case of the 2nd internode, irrespective of the cultivar (Fig. 6). The $B s$ value for the 2 nd internode was, on average, $360 \mathrm{Nm}$, and it was $25 \%$ higher as compared with the 3rd one. In Dańkowskie Diament, the decrease in the strength of the 2nd internode was greatest as compared with the $3 \mathrm{rd}$ one $(125 \mathrm{Nm})$ in which the value of the failure moment was significantly the lowest $(250 \mathrm{Nm})$ as compared with the other cultivars. In contrast, in Antonińskie, the strength of the 3rd internode was only $50 \mathrm{Nm}$ lower as compared with the $2 \mathrm{nd}$ one.

The assessment of the correlations between the analysed parameters has shown that for all of the cultivars in the 2 nd and, in the case of the majority of cultivars, in the 3rd internode a significant linear, positive correlation $\left(r>0.680^{* *}\right)$ between the stem diameter and the central canal diameter occurs (Table 3). No distinct relationship between these two parameters of the stem anatomical structure and the stem wall thickness was found. However, the stem wall thickness was significantly related to the thickness of the parenchyma (up to $r=0.956^{* *}$ in Dańkowskie Amber). The value of the stem failure moment $(B s)$, in both the internodes and in all the cultivars, was significantly correlated only with the stem diameter and ranged from $r=0.638^{* *}$ (Dańkowskie Rubin) to $r=0.986^{* *}$ (Dańkowskie Amber). Besides, for all of the cultivars, strong correlations between $B s$ and stem wall thickness $\left(r>0.598^{* *}\right)$ were found, but only for the 2nd internode. 

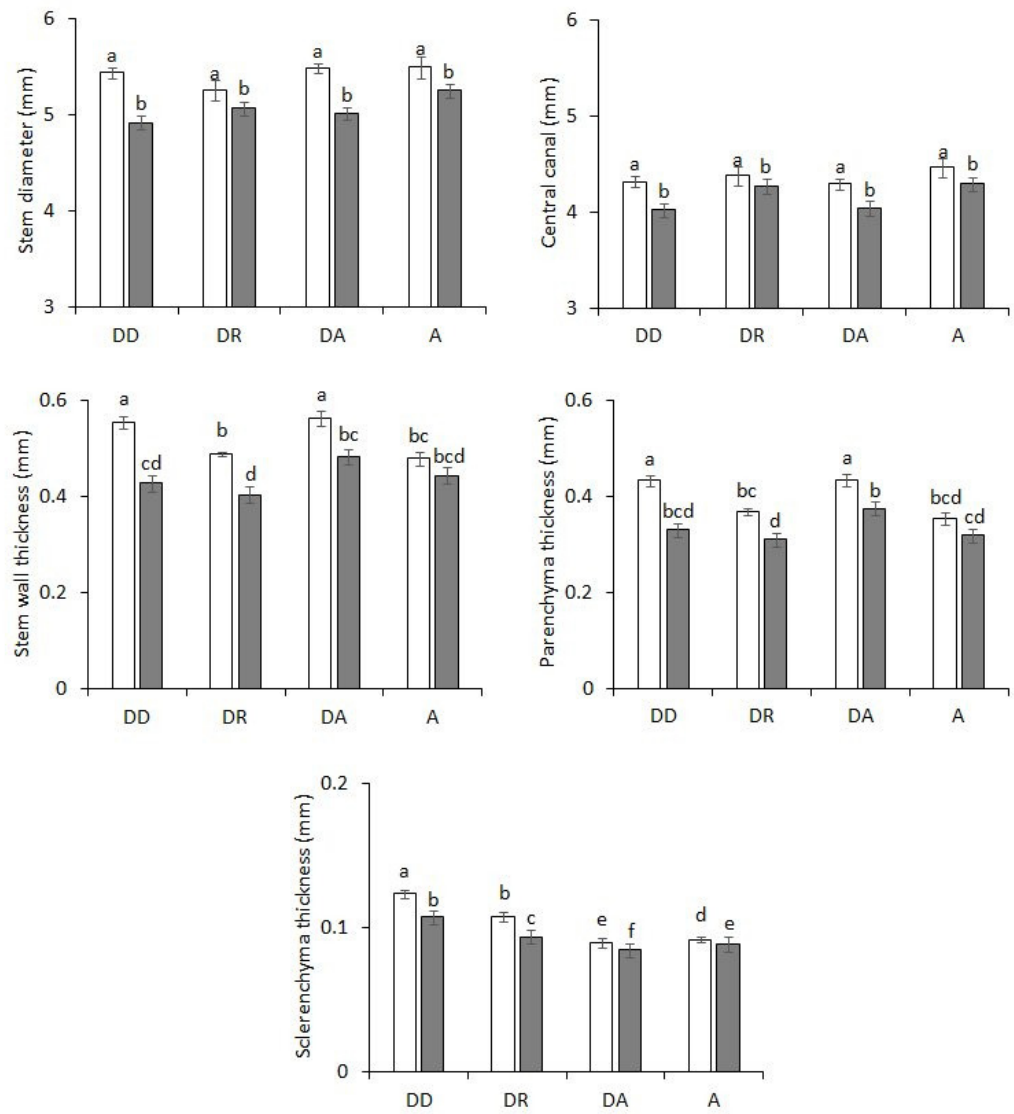

Fig. 4. Cultivar differentiation in the morphological and anatomical traits of the stem at the 2nd and 3rd internodes; DD - Dańkowskie Diament, DR - Dańkowskie Rubin, DA - Dańkowskie Amber, A - Antonińskie (the means marked with the same letter for a given trait do not differ significantly according to the Tukey HSD test at $\mathrm{p}<0.05$; error bars represent mean values \pm standard error).
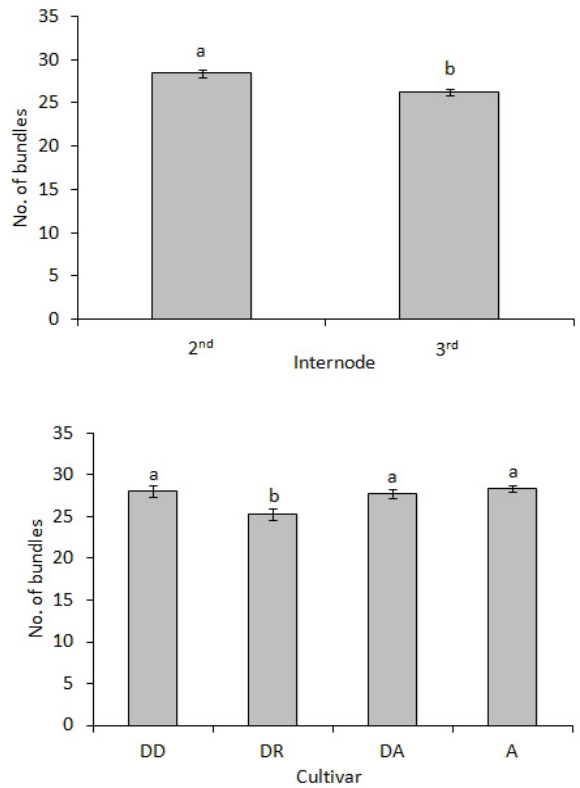

Fig. 5. Number of large vascular bundles in the 2nd and 3rd internodes and in the studied rye cultivars; DD - Dańkowskie Diament, DR - Dańkowskie Rubin, DA - Dańkowskie Amber, A - Antonińskie (the means marked with the same letter do not differ significantly according to the Tukey HSD test at $\mathrm{p}<0.05$; error bars represent mean values \pm standard error).

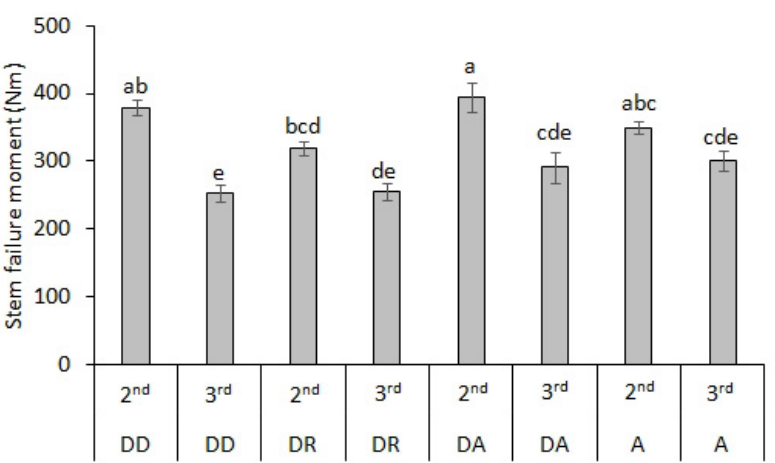

Fig. 6. Differentiation in the stem failure moment in the 2 nd and 3rd internodes in the tested cultivars; DD - Dańkowskie Diament, DR - Dańkowskie Rubin, DA - Dańkowskie Amber, A - Antonińskie (the means marked with the same letter do not differ significantly according to the Tukey HSD test at $p<0.05$; error bars represent mean values \pm standard error).

\section{DISCUSSION}

The morphoanatomical properties of plants, conditioned by the genotype, seem to be crucial for their mechanical resistance to unfavourable environmental conditions. In many cultivated species, the permanent movement of plant shoots relative to their vertical position may be observed. 


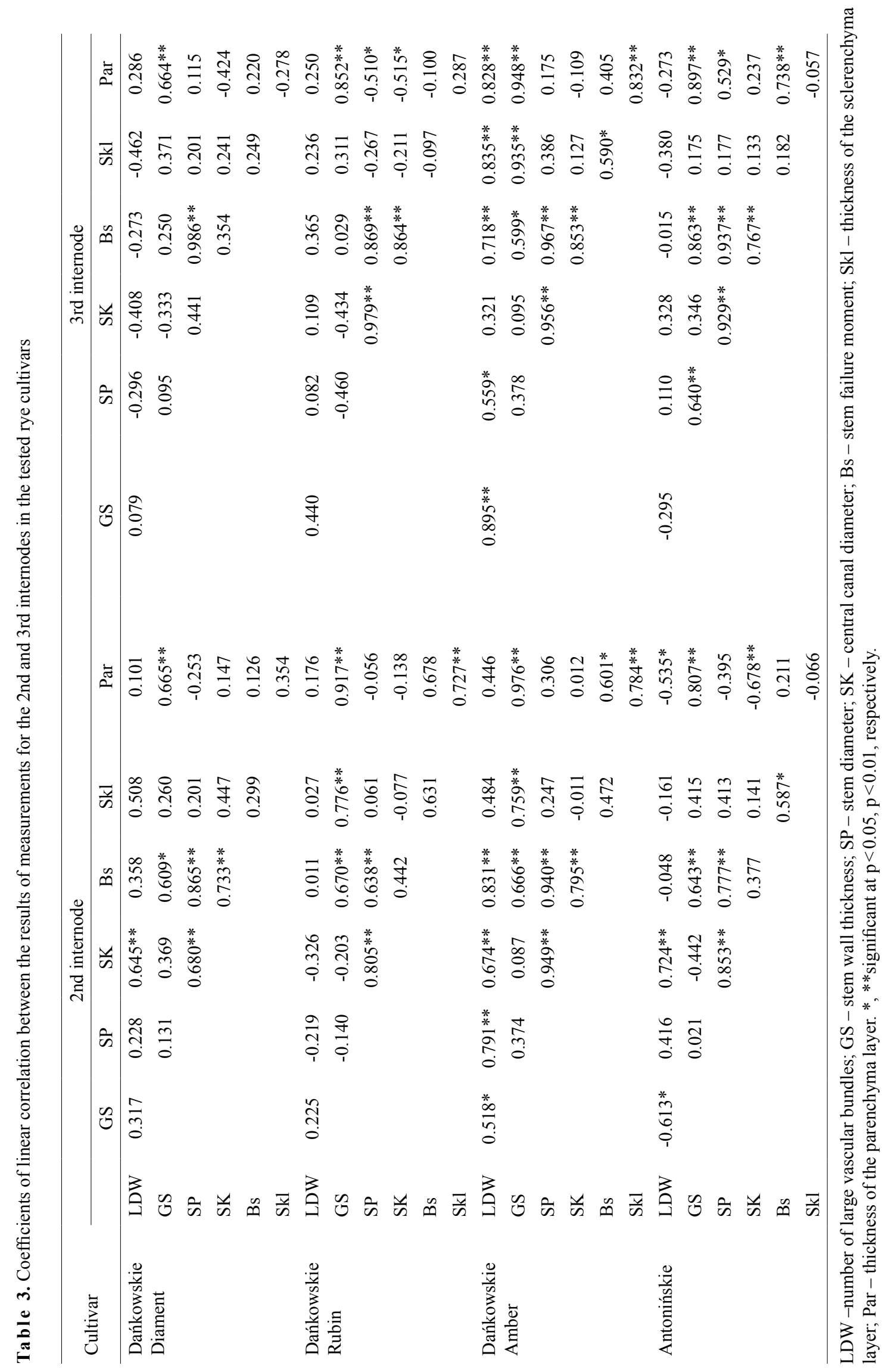


This phenomenon takes place mainly in the regions where irrigation is used or where precipitation and wind occur (Baker et al., 2014). The susceptibility of plant shoots to the action of dynamic and static forces resulting in, for example, lodging is connected with the characteristic structure of the cereal stems (Ren et al., 2013). Special attention is drawn to stem length, the length of the lower internodes, the diameters of stem cross sections, as well as stem wall thickness, the number of vascular bundles and the share of strengthening tissues (thickness of the mechanical layer) which show strong correlations with the resistance to lodging (Kelbert et al., 2004). As compared with research works concerning wheat stem anatomy, analogical works on rye are scarce. In the research carried out, small but significant differentiation in the selected traits of the studied cultivars was found. Only the stem diameter in the four analysed genotypes showed the statistical similarity of the cultivars and it was, on average, $0.5 \mathrm{~mm}$ greater than that found by Jagodziński (2005) when investigating rye populations. This result partially corresponds with reports indicating the possibility of the occurrence of a similar reaction with regards to the action of uniform agrotechnical and habitat factors during plant growth on the elements of morphological structure also in other cereal species (Leblicq et al., 2015). The stem diameter is considered to be the key parameter affecting the mechanical strength of the stem (Hall et al., 2010). It is of special importance in maintaining the mass of the generative elements, which appear during plant growth on the stem top. On occasion, even if the growing conditions favour high seed yield, it is mere gravitation that may be the cause of bending or the increased fragility of stems (Li et al., 2011). However, the decisive role in this respect is played by cultivar diversity, which under the conditions of the field experiment carried out, contributed to the revelation of genotypic differences in the remaining analysed traits. The cultivars Dańkowskie Amber and Diament in both analysed internodes were characterized by the lowest values of the central canal diameter, showing thereby $0.23 \mathrm{~mm}$ thicker stem walls as compared with other genotypes. These values, especially in relation to the stem wall thickness, could indicate the increased mechanical strength of the stem, which is so important during the grain-filling period and harvest (Piñera-Chavez et al., 2016). However, other authors often suggest that plants with a less well-formed habit, shorter and with a smaller mass show greater pneumatic adaptation to the action of static or dynamic forces (Gardiner et al., 2016). The fact that for all of the cultivars, the stem diameter of the 2nd internode was, on average, $0.4 \mathrm{~mm}$ greater as compared with the 3 rd internode, points to the strategic role of this part of the stem in stabilizing the overground part of the plant, which has already been described by other authors (Packa et al., 2015; Zheng et al., 2017). The microscopy observations carried out point to the 2 nd internode as the fragment accumulating significant potential for the mechanical strength of the stem. The characteristic distribution of the strengthening tissues observed in the cross section of the hollow stem in which sclerenchyma or xylem are moved as far as possible from the stem axis, suggests the tendency to develop a perfect pneumatic and mechanical structure of the stem (Schulgasser and Witztum, 1997). Such an "evolutionary protection" at the genotype level confirms the occurrence of an identical number of vascular bundles in the majority, i.e. three of the four analysed genotypes. From a biomechanical point of view, the greater share of stiffening elements positioned as far as possible from the centre of gravity of the stem limits the inertia and improves the stabilization relative to the ground (Cowin and Doty, 2007). The chemical composition of the cell walls modulated by lignin, cellulose, hemicellulose, carbohydrates, suberin or silicon content plays a strategic role with regard to the strength of the tissues at the stem base (Kong et al., 2013). The denser concentration of the vascular bundles in the peripheral part of the stem, having a similar diameter, due to the accompanying strengthening elements, was reflected in the thickness of the sclerenchyma, which in all the cultivars in the 2nd internode was $10 \%$ greater as compared with the 3rd one. The main structural component of the secondary cell walls, providing stiffness and strength within the sclerenchyma is lignin, a phytochemical biopolymer showing the greatest hardness, which determines the mechanical strength of plants (Thakur et al., 2014). The research carried out by Wang et al. (2014) and Begović et al. (2015) on barley have unambiguously showed that the lignin content of the subepidermal mechanical layer and in the sclerenchyma surrounding vascular bundles significantly affects the resistance to lodging. The observations of the sections, after carrying out the Wiesner reaction, showed that in the examined rye cultivars, the majority of cells forming the stem had walls encrusted with lignin also in the parenchymal area, which is probably one of the factors determining their favourable mechanical parameters, which were demonstrated in the cultivar experiments (LOO, 2018).

The thickest sclerenchyma layer, both in the 2nd and 3rd internodes, was found in Dańkowskie Diament $(0.12 \mathrm{~mm})$. Also, this genotype was in the group of cultivars showing the statistically significant highest values of all of the remaining parameters analysed at the 2 nd internode. Shah et al. (2017) showed that cultivars with a high accumulation of lignin in the strengthening tissues may be successfully used in breeding for an increased resistance to lodging. However, because of the lowest values of stem thickness in the 3rd internode in Dańkowskie Diament, the greatest $(32 \%)$ decrease in the stem failure (Bs) was found. Similar statistical differences were found for the second cultivar with the highest $B s(395 \mathrm{Nm})$ - Dańkowskie Amber. Such sharp differences in the values of the mechanical strength indices were observed previously in other research works (Baker et al., 2014; Piñera-Chavez et al., 2016). The 
authors suggested that attention should be focused on a uniform habit of neighbouring internodes. The proposed use of rye straw for the production of drinking straws, as an alternative to the commonly used polyurethane straws, would have to be connected with the use of plants, which were only characterized by these properties, i.e. uniform along the whole usable length of the stem. In this study, the cultivar which was least differentiated with respect to $B s$ was Antonińskie, in which for both of the analysed stem fragments, the difference in the failure moments was only $15 \%$. The plants of that cultivar, in spite of the fact that their stem diameter was comparable with that of other cultivars, were also characterized by the greatest diameter of the central canal, as well as the lowest number of vascular bundles in both of the analysed internodes.

The highly significant positive values of the coefficients of the linear correlation between the stem diameter and the diameter of the central canal showed, in the 2 nd internode, the determination coefficient $\left(r^{2}\right)$ of these parameters ranging from $46 \%$ in Dańkowskie Diament to $90 \%$ in Dańkowskie Amber. Such genotypic differentiation may indicate the possibility of using the latter cultivar in a breeding programme. This is confirmed by the high values of the coefficients of determination $\left(r^{2}>56 \%\right)$ between parenchyma and sclerenchyma thicknesses and the stem wall thickness. Berry et al. (2003) and Peng et al. (2014) have previously shown the significant correlation between the strength of stems and lignin and hemicellulose contents of sclerenchyma, which suggests that cultivars with a higher accumulation of lignin should be used in breeding in order to improve the mechanical strength of stems. It was found that none of the genotypes showed a significant linear correlation between the stem diameter, the central canal diameter and the stem wall thickness. However, the stem diameter showed positive, high correlations with the $B s$. Such correlations in various species have previously been reported by other authors (Kamran et al., 2018).

\section{CONCLUSIONS}

1. The results of the research have shown significant cultivar differentiation in the morphological and anatomical properties determining the resistance to bending and the possible use of rye stems in the manufacture of natural drinking straws.

2. The analyses carried out and the assessment of the correlations between the selected parameters have shown that it is the 2nd internode that is characterized by the most favourable properties with respect to the mechanical strength of rye stems.

3. The lowest differentiation of the stem mechanical strength parameters in the tested internodes was found in the Antonińskie cultivar, which was characterized by the largest diameter of the central canal, indicating its possible use in the production of drinking straws.
4. The analyses carried out may be the first step towards studies aimed at determining Polish rye cultivars useful for the manufacture of drinking straws.

Conflict of interest: The Authors declare no conflict of interest.

\section{REFERENCES}

Baker C.J., Berry P.M., Spink J.H., Sylvester-Bradley R., Griffin J.M., Scott R.K., and Clare R.W., 1998. A method for the assessment of the risk of wheat lodging. J. Theoretical Biol., 194(4), 587-603. https://doi.org/10.1006/jtbi.1998.0778

Baker C.J., Sterling M., and Berry P., 2014. A generalised model of crop lodging. J. Theoretical Biol., 363, 1-12. https://doi.org/10.1016/j.jtbi.2014.07.032

Baron V.S., Juskiw P.E., and Aljarrah M., 2015. Triticale as a forage. In: Triticale, Springer, Cham., 189-212. https://doi.org/10.1007/978-3-319-22551-7_10

Begović L., Ravlić J., Lepeduš H., Leljak-Levanić D., and Cesar V., 2015. The pattern of lignin deposition in the cell walls of internodes during barley (Hordeum vulgare L.) development. Acta Biologica Cracoviensia s. Botanica, 57(2), 55-66. https://doi.org/10.1515/abcsb-2015-0017

Berry P.M., Spink J.H., Gay A.P., and Craigon J., 2003. A comparison of root and stem lodging risks among winter wheat cultivars. J. Agric. Sci., 141(2), 191-202. https://doi.org/10.1017/s002185960300354x

Călinoiu L.F. and Vodnar D.C., 2018. Whole grains and phenolic acids: A review on bioactivity, functionality, health benefits and bioavailability. Nutrients, (10)11, 1615. https://doi.org/10.3390/nu10111615

Cowin S.C. and Doty S.B., 2007. Tissue mechanics. Springer Science \& Business Media.

EC, 2018. Directive of the European Parliament and of the Council on the reduction of the impact of certain plastic products on the environment. EUR-Lex - 52018PC0340 EN, 28.5.2018, Brussels, Belgium.

Falke K.C., Wilde P., Wortmann, H., Geiger, H.H., and Miedaner T., 2009. Identification of genomic regions carrying QTL for agronomic and quality traits in rye (Secale cereale) introgression libraries. Plant Breeding, 128, 615-623. https://doi.org/10.1111/j.1439-0523.2009.01644.x

FAOSTAT, 2019. http://www.fao.org/faostat/en/\#data/QC.

Gardiner B., Berry P., and Moulia B., 2016. Wind impacts on plant growth, mechanics and damage. Plant Sci., 245, 94-118. https://doi.org/10.1016/j.plantsci.2016.01.006

Hall A.J., Sposaro M.M., and Chimenti C.A., 2010. Stem lodging in sunflower: variations in stem failure moment of force and structure across crop population densities and post-anthesis developmental stages in two genotypes of contrasting susceptibility to lodging. Field Crops Res., 116(1-2), 46-51. https://doi.org/10.1016/j.fcr.2009.11.008

Jagodziński J., 2005. Variability of some culm morphological and mechanical traits in inbred lines of rye (in Polish). Biuletyn Instytutu Hodowli i Aklimatyzacji Roślin, 235, 243-249.

Jambeck J.R., Geyer R., Wilcox C., Siegler T.R., Perryman M., Andrady A., and Law K.L., 2015. Plastic waste inputs from land into the ocean. Science, 347(6223), 768-771. https://doi.org/10.1126/science. 1260352 
Kamran M., Cui W., Ahmad I., Meng X., Zhang X., Su W., Chen J., Ahmad S., Fahad S., Han Q., and Liu T., 2018. Effect of paclobutrazol, a potential growth regulator on stalk mechanical strength, lignin accumulation and its relation with lodging resistance of maize. Plant Growth Regulation, 84(2), 317-332.

https://doi.org/10.1007/s10725-017-0342-8

Kelbert A.J., Spaner D., Briggs K.G., and King J.R., 2004. The association of culm anatomy with lodging susceptibility in modern spring wheat genotypes. Euphytica, 136(2), 211-221. https://doi.org/10.1023/b:euph.0000030668.62653.0d

Kong E., Liu D., Guo X., Yang W., Sun J., Li X., Zhan K., Cui D., Lin J., and Zhang A., 2013. Anatomical and chemical characteristics associated with lodging resistance in wheat. Crop J., 1(1), 43-49. https://doi.org/10.1016/j.cj.2013.07.012

Lancashire P.D., Bleiholder H., Boom T.V.D., Langelüddeke P., Stauss R., Weber E., and Witzenberger A., 1991. A uniform decimal code for growth stages of crops and weeds. Annals of Appl. Biol., 119(3), 561-601.

https://doi.org/10.1111/j.1744-7348.1991.tb04895.x

Leblicq T., Vanmaercke S., Ramon H., and Saeys W., 2015. Mechanical analysis of the bending behaviour of plant stems. Biosys. Eng., 129, 87-99. https://doi.org/10.1016/j.biosystemseng.2014.09.016

Li J., Zhang H.C., Gong J.L., Chang Y., Dai Q.G., Huo Z.Y., Ke X., and Wei H.Y., 2011. Effects of different planting methods on the culm lodging resistance of super rice. Scienta Agricultura Sinica, 44(11), 2234-2243.

LOO, 2018. Descriptive List of Cultivar Plants (in Polish). COBORU, Słupia Wielka, Poland.

Packa D., Wiwart M., Suchowilska E., and Bieńkowska T., 2015. Morpho-anatomical traits of two lowest internodes related to lodging resistance in selected genotypes of Triticum. Int. Agrophys., 29(4), 475-483.

https://doi.org/10.1515/intag-2015-0053

Peng D., Chen X., Yin Y., Lu K., Yang W., Tang Y., and Wang Z., 2014. Lodging resistance of winter wheat (Triticum aestivum L.): Lignin accumulation and its related enzymes activities due to the application of paclobutrazol or gibberellin acid. Field Crops Res., 157, 1-7. https://doi.org/10.1016/j.fcr.2013.11.015
Piñera-Chavez F.J., Berry P.M., Foulkes M.J., Jesson M.A., and Reynolds M.P., 2016. Avoiding lodging in irrigated spring wheat. I. Stem and root structural requirements. Field Crops Res., 196, 325-336. https://doi.org/10.1016/j.fcr.2016.06.009

Ren B.Z., Zhang J.W., Li X., Fan X., Dong S.T., Liu P., and Zhao B., 2013. Effects of waterlogging on stem lodging resistance of summer maize under field conditions. Scientia Agricultura Sinica, 12, 2440-2448. https://doi.org/10.3724/sp.j.1006.2012.02093

Rueden C.T., Schindelin J., Hiner M.C., DeZonia B.E., Walter A.E., Arena E.T., and Eliceiri K.W., 2017. ImageJ2: ImageJ for the next generation of scientific image data. BMC Bioinformatics, 18(1), 529. https://doi.org/10.1186/s12859-017-1934-Z

Schulgasser K. and Witztum A., 1997. On the strength of herbaceous vascular plant stems. Annals of Botany, 80(1), 35-44. https://doi.org/10.1006/anbo.1997.0404

Searle S.R., Casella G., and McCulloch C.E., 2006. Variance components. Wiley Series in Probability and Statistics. J. Wiley and Sons, Hoboken, New Jersey, USA. https://doi.org/10.1002/9780470316856

Shah A.N., Tanveer M., ur Rehman A., Anjum S.A., Iqbal J., and Ahmad R., 2017. Lodging stress in cereal - effects and management: an overview. Environ. Sci. Poll. Res., 24(6), 5222-5237. https://doi.org/10.1007/s11356-016-8237-1

Šíp V., Chrpová J., Žofajová A., Pánková K., Užík M., and Snape J.W., 2010. Effects of specific Rht and Ppd alleles on agronomic traits in winter wheat cultivars grown in middle Europe. Euphytica, 172(2), 221-233. https://doi.org/10.1007/s10681-009-0049-7

Thakur V.K., Thaku M.K., Raghavan P., and Kessler M.R., 2014. Progress in green polymer composites from lignin for multifunctional applications: a review. ACS Sustainable Chemistry Eng., 2(5), 1072-1092. https://doi.org/10.1021/sc500087z

Wang J., Yang J., Jia Q., Zhu J., Shang Y., Hua W., and Zhou M., 2014. A new QTL for plant height in barley (Hordeum vulgare L.) showing no negative effects on grain yield. Plos one, 9(2), e90144.

Zheng M., Chen J., Shi Y., Li Y., Yin Y., Yang D., Luo Y., Pang D., Xu X., Li W., Ni J., Wang Y., Wang Z., and Li Y., 2017. Manipulation of lignin metabolism by plant densities and its relationship with lodging resistance in wheat. Scientific Reports, 7, 41805. https://doi.org/10.1038/srep41805 